\title{
Evaluation of Antidiabetic Activity of Aqueous and Etylic alcohol Extracts of Stem Bark of Xylopia villosa Chipp (Annonaceae)
}

\author{
Kouame Yao Yves ${ }^{1, *}$, Okpekon Aboua Timothée ${ }^{2}$, Yapi Houphouët Félix ${ }^{1}$ \\ ${ }^{1}$ Laboratory of Pharmacodynamics Biochemical, UFR Biosciences, Felix Houphouet Boigny University, Cote d'Ivoire \\ ${ }^{2}$ Laboratory of Organic Chemistry and Natural Substances, UFR Sciences of Structures of Matter and Technology, Felix Houphouet \\ Boigny University, Cote d'Ivoire
}

Copyright(C2017 by authors, all rights reserved. Authors agree that this article remains permanently open access under the terms of the Creative Commons Attribution License 4.0 International License

\begin{abstract}
This study aims to evaluate antidiabetic activity of aqueous and ethanolic extracts of Xylopia villosa stem bark. Induction of diabetes was made with Streptozocin on male rats. Treatments of diabetic rats with aqueous and ethanolic extracts of Xylopia villosa at doses of 100 and $200 \mathrm{mg} / \mathrm{kg}$ bw and Daonil (the reference molecule) at doses of 10 and $20 \mathrm{mg} / \mathrm{kg}$ bw revealed that ethanolic extract (200 mg / kg) bw behaved like Daonil (20 mg / kg bw). It is the therapeutic dose needed to correct hyperglycaemia. At this dose, the ethanolic extract allowed an important insulin secretion equivalent to the non-diabetic control rats and allowed the gradual reconstitution of the islets of Langerhans and the reappearance of the $\beta$ cells responsible for the secretion of the insulin. This situation would be linked to the flavonoids and zinc contained in the extracts. Indeed, Zinc, in addition to being a powerful antioxidant, would have a protective insulin action and an important insulin-like effect by activating the kinases involved in insulin signaling and the phosphorylations necessary for insulin efficacy. Also, flavonoids improve the sensitivity of the body's cells to insulin, which reduces the incidence of type 2 diabetes.
\end{abstract}

Keywords Xylopia villosa, Streptozocin, Antidiabetic, Glycaemia, Insulin

\section{Introduction}

Diabetes is a chronic disease that occurs when the pancreas does not produce enough insulin or when the body is unable to effectively use the insulin it produces. This results in an increased concentration of glucose in the blood (hyperglycemia). According to the criteria of the World Health Organization, diabetes occurs when fasting blood glucose is greater than or equal to $7 \mathrm{mmol} / \mathrm{L}$ or $1.26 \mathrm{~g} / \mathrm{L}$ twice [1]. The number of people with diabetes rose from 108 million in 1980 to 422 million in 2014. The global prevalence of diabetes among adults over 18 years rose from $4.7 \%$ in 1980 to $8.5 \%$ in 2014 [1]. The prevalence of diabetes has increased more rapidly in low- and middle-income countries [1]. It increases the risk of cardiac or cerebrovascular accidents in adults and is one of the leading causes of kidney failure [1]. WHO projects that diabetes will be the 7 th leading cause of death in 2030[2]. Diabetes is gaining momentum and constitutes an additional economic problem for those affected. The Ivorian flora, which has 3853 species of vascular plants distributed between forests and savannas [3], turns out to be an emergency exit for the search for antidiabetic drugs.

Xylopia villosa Chipp, a species of this flora is used in traditional medicine in Africa to treat various pathologies including colds and headaches. Its crushed seeds are applied to leg ulcers and boils for healing [4]. Recently, Kouamé and al [5-7] carried out the study of triphytochemistry and acute toxicity, the study of the anti-inflammatory and antioxidant activities of Xylopia villosa Chipp. However, the antidiabetic activity of Xylopia villosa Chipp is not yet known. The objective of this study was to evaluate Xylopia villosa Chipp by evaluating its antidiabetic activity. To achieve this, the specific objectives were to induce diabetes with streptozocin and to determine the effect of extracts of Xylopia villosa Chipp on blood glucose and insulin levels in diabetic rats to carry out the histological sections of the pancreas of the diabetic rats.

\section{Materials and Methods}

\subsection{Plant Material}

Xylopia villosa stems bark were harvested in June 2014 at the National Floristic Center of Felix Houphouët Boigny University where can be found a sample recorded at the 
number 14712.

\subsection{Preparation of Extracts}

The stems bark of Xylopia villosa were dried for four weeks in the shade of the sun then made powder using an electric grinder IKAMAG RCT ${ }^{\circledR}$. Hundred (100) grams of powder of Xylopia villosa were macerated for 24 hours in 1 liter of ethylic alcohol (ethylic alcohol and distilled water mixture: 70/30). The macerated obtained was then filtered twice on white cotton and once on Whatman filter paper $\mathrm{N}^{\circ} 4$. The filtrate obtained in $70 \%$ ethanol was evaporated to dryness at reduced pressure at temperature of $40^{\circ} \mathrm{C}$ using a rotary evaporator type Buchi 161 Water Bath. About aqueous extract preparation, 100 grams of Xylopia villosa stem barks powder were added to 100 milliliters of boiling distilled water. Just like ethanolic preparation, the resulting mixture was filtered twice on white cotton and once on Whatman filter paper $\mathrm{N}^{\circ} 4$. The filtrate obtained is preserved at temperature of $40^{\circ} \mathrm{C}$ in an oven for drying.

\subsection{Determination of Trace Elements in Aqueous and Ethanolic Extracts of Xylopia villosa}

The determination of the trace elements in aqueous and ethylic alcohol extracts of Xylopia villosa was carried out according to the method of Clément and Françoise [8]. The aqueous and ethylic alcohol extracts of Xylopia villosa were dried for 24 hours in a Memmert-Germany oven at $60^{\circ} \mathrm{C}$. Then, they were kept in glass jars.

\subsubsection{Mineralization by Calcination}

For each of the extracts (aqueous and ethylic alcohol) dried in an oven at $60^{\circ} \mathrm{C}$. $0.4 \mathrm{~g}$ was weighed using a Sartorius analytic (England) scale in a $30 \mathrm{ml}$ porcelain crucible. This test portion was placed in the Naberthem-Germany muffle furnace set at $550^{\circ} \mathrm{C}$. for 5 hours. After cooling, $2 \mathrm{ml}$ of $0.5 \mathrm{~N}$ chloridic acids were added to the ash obtained and then brought to total evaporation on a sand bath. The recovered final residue was filtered through a $100 \mathrm{~mL}$ volumetric flask and distilled water was added to reach the gauge mark. Five (5) $\mathrm{mL}$ of the filtrate were taken for the determination of the minerals Five (5) $\mathrm{mL}$ of the same filtrate was also removed for the determination of the minerals (Potassium, Iron, Zinc, Magnesium, Copper) by the atomic absorption spectrophotometer AAS 20 type VARIAN, Australia).

\subsubsection{Preparation of the Lanthanum Reagent $\left(\mathrm{La}_{2} \mathrm{O}_{3}\right)$}

Under a hood, a mass of $58.65 \mathrm{~g}$ of $\mathrm{La}_{2} \mathrm{O}_{3}$ was wetted with $50 \mathrm{~mL}$ of distilled water and $250 \mathrm{~mL}$ of concentrated hydrochloric acid was added thereto with slow stirring until the lanthanum was completely diluted. Before any reading, the atomic absorption spectrophotometer was calibrated. To do this, a standard solution of $100 \mathrm{ppm}$ was prepared from a commercial solution called a multi-element of $1000 \mathrm{ppm}$. The preparation was carried out as follows: $2.5 \mathrm{~mL}$ of the stock solution (1000 ppm) was added to a $25 \mathrm{~mL}$ flask and supplemented with concentrated nitric acid to the gauge mark and this solution was used to prepare the standard ranges.

\subsubsection{Preparation of Samples and Standards}

Five (5) $\mathrm{mL}$ of each sample was taken from a $50 \mathrm{~mL}$ vial and $2 \mathrm{~mL}$ of $5 \%$ Lanthanum was added to it before completing with distilled water to the mark. For standards, dilutions from standard solutions of each mineral (100 $\mathrm{mg} / \mathrm{L}$ ) are performed by supplementing the initial volumes to $50 \mathrm{~mL}$ with distilled water, so as to obtain an accurate concentration range for each mineral. These calibration solutions are then used for the calibration of the flame atomic absorption spectrophotometer. To determine the different quantities of stock solution $(\mathrm{mL})$ to be taken, the following procedure was adopted:

$\mathbf{C}_{\mathrm{i}} \mathbf{V}_{\mathrm{i}}=\mathbf{C}_{\mathrm{f}} \mathbf{V}_{\mathrm{f}}$

With: $\mathbf{C}_{\mathbf{f}}$ : final concentration of the mineral solution (100 ppm)

$$
\begin{aligned}
& \mathbf{C}_{\mathrm{i}} \text { : initial concentration of the mineral solution (1 } \\
& \mathrm{mg} / \mathrm{mL}) \\
& \left.\mathbf{V}_{\mathrm{i}}: \text { initial volume taken (variable) (in } \mathrm{mL}\right) \\
& \mathbf{V}_{\mathbf{f}} \text { : final volume }(\mathrm{mL})
\end{aligned}
$$

The wavelengths at which potassium, iron, zinc, magnesium and copper were read were $766.5 \mathrm{~nm} ; 248.3 \mathrm{~nm}$; $258 \mathrm{~nm} ; 285.2 \mathrm{~nm}$ and $324.7 \mathrm{~nm}$ respectively. The results of the optical densities of each mineral made it possible to determine the quantities of minerals (ppm) contained in the aqueous and ethylic alcohol extracts. The mineral contents were determined as follows:

$$
\mathbf{T}=\left[\left(\mathbf{C}_{\text {ess }}-\mathbf{C}_{\text {wh }}\right) \times \mathbf{V}\right] / \mathbf{P}_{\text {ess }}
$$

With: $\mathbf{C}_{\text {ess }}$ : concentration of the sample $(\mathrm{mg} / \mathrm{mL})$

$\mathbf{C}_{\mathrm{wh}}$ : white concentration in $\mathrm{mg} / \mathrm{mL}$

$\mathbf{P}_{\text {ess: }}$ : test portion $(\mathrm{Kg})$

V: recovery volume of test $(\mathrm{mL})$

T: content of $\mu \mathrm{g} / \mathrm{g}$ or $\mathrm{mg} / \mathrm{Kg}$

\subsection{Reagents, Solvents and Drugs for Antidiabetic Activity}

All products used in this study were provided by Sigma Aldrich Ltd (Paris, France).

\subsection{Experimental Animals}

In this experiment, 60 wistar albino male rats of 11 weeks old and mean weight $149.02 \pm 0.10$ grams were used. First, a control group of 6 non-diabetic rats was formed. Secondly, 54 non-diabetic rats received streptozocin intravenously at a dose of $60 \mathrm{mg} / \mathrm{kg}$ body weight. The evolution of glycaemia of rats was followed from day D0 to D7 using strip glucose meter. At the 7 th day after streptozocin injection, 42 diabetic rats were selected and divided into 7 groups of 6 rats according to their glycaemia. Subsequently, a treatment by gavage took place during 6 days with the different drugs according to the following distribution: 
- $\quad$ Non-diabetic control group $\rightarrow 1 \mathrm{~mL}$ of distilled water

- $\quad$ Untreated diabetic group $\rightarrow 1 \mathrm{~mL}$ of distilled water

- $\quad$ Treated diabetic group $\rightarrow 1 \mathrm{~mL}$ of aqueous extract 100 $\mathrm{mg} / \mathrm{kg}$ bw

- $\quad$ Treated diabetic group $\rightarrow 1 \mathrm{~mL}$ of aqueous extract 200 $\mathrm{mg} / \mathrm{kg}$ bw

- $\quad$ Treated diabetic group $\rightarrow 1 \mathrm{~mL}$ of ethylic alcohol extract $100 \mathrm{mg} / \mathrm{kg}$ bw

- $\quad$ Treated diabetic group $\rightarrow 1 \mathrm{~mL}$ of ethylic alcohol extract $200 \mathrm{mg} / \mathrm{kg}$ bw

- $\quad$ Treated diabetic group $\rightarrow 1 \mathrm{~mL}$ Daonil ${ }^{\circledR} 10 \mathrm{mg} / \mathrm{kg}$ bw

- $\quad$ Treated diabetic group $\rightarrow 1 \mathrm{~mL}$ Daonil ${ }^{\circledR} 20 \mathrm{mg} / \mathrm{kg}$ bw

Finally, after 6 days of treatment, blood and pancreas were taken by the method of decapitation, which consists in cutting the neck of the rat with a knife blade. The rat thus decapitated is placed immediately above the sampling tubes containing sodium fluoride. The pancreas was extracted and put in $10 \%$ formaldehyde for storage before microtome cutting and histological study.

\section{Results}

\subsection{Trace Element Content}

The trace element content (Potassium, Iron, Zinc, Magnesium, and Copper) in aqueous and ethylic alcohol extracts of Xylopia villosa are summarized in Table I.

Table 1. Trace element content in aqueous and ethanolic extracts of Xylopia villosa

\begin{tabular}{|c|c|c|}
\hline \multirow{2}{*}{ Trace element } & \multicolumn{2}{|c|}{$\begin{array}{c}\text { Trace element content }(\boldsymbol{\mu g} / \mathbf{g} \text { of dry } \\
\text { extract) }\end{array}$} \\
\cline { 2 - 3 } & Aqueous extract & $\begin{array}{c}\text { Ethylic alcohol } \\
\text { extract }\end{array}$ \\
\hline Potassium & $19971,00 \pm 37,02$ & $19128,00 \pm 203,80$ \\
\hline Iron & $16,25 \pm 0,36$ & $10,11 \pm 0,26$ \\
\hline Zinc & $9,34 \pm 0,26$ & $13,74 \pm 0,16$ \\
\hline Magnesium & $1628,00 \pm 14,86$ & $1405,00 \pm 6,56$ \\
\hline Copper & $44,87 \pm 0,15$ & $50,20 \pm 0,25$ \\
\hline
\end{tabular}

\subsection{Evolution of Glycaemia after Injection of Streptozotocin}

The mean glycaemia of rats before streptozocin injection was $0.97 \pm 0.09 \mathrm{~g} / \mathrm{L}$. After streptozocin injection, glycaemia rate increased to $1.28 \pm 0.15 \mathrm{~g} / \mathrm{L}$ on $2 \mathrm{nd}$ day, $1.48 \pm 0.18 \mathrm{~g} /$ $\mathrm{L}$ on 4 th day, $1.75 \pm 0.13 \mathrm{~g} / \mathrm{L}$ on 6 th day and $3.32 \pm 0.35 \mathrm{~g} /$ L on 7 th day (Fig. 1).

\subsection{Categorization of Rats}

Fig. 2 shows the different groups of diabetic rats before their treatment. They were grouped according to the glycaemia as follows. Non-diabetic control group (0.98 \pm $0.04 \mathrm{~g} / \mathrm{L})$, untreated diabetic group $(2.98 \pm 0.06 \mathrm{~g} / \mathrm{L})$, diabetic group (Aqueous extract $100 \mathrm{mg} / \mathrm{kg} \mathrm{bw}: 3.09 \pm 0.05$ $\mathrm{g} / \mathrm{L}$ ), diabetic group (ethylic alcohol extract $100 \mathrm{mg} / \mathrm{kg} \mathrm{bw}$ : $3.23 \pm 0.06 \mathrm{~g} / \mathrm{L}$ ), diabetic group (Daonil ${ }^{\circledR} 10 \mathrm{mg} / \mathrm{kg}$ bw: 3.30 $\pm 0.06 \mathrm{~g} / \mathrm{L}$ ), diabetic group (Aqueous extract $200 \mathrm{mg} / \mathrm{kg}$ bw: $3.54 \pm 0.06 \mathrm{~g} / \mathrm{L}$ ), diabetic group (ethylic alcohol extract 200 $\mathrm{mg} / \mathrm{kg}$ bw: $3.57 \pm 0.05 \mathrm{~g} / \mathrm{L}$ ) and diabetic group (Daonil ${ }^{\circledR} 20$ $\mathrm{mg} / \mathrm{kg}$ bw: $3.61 \pm 0.06 \mathrm{~g} / \mathrm{L})$. These different glycaemia are high compared to the glycaemia of non-diabetic control rats.

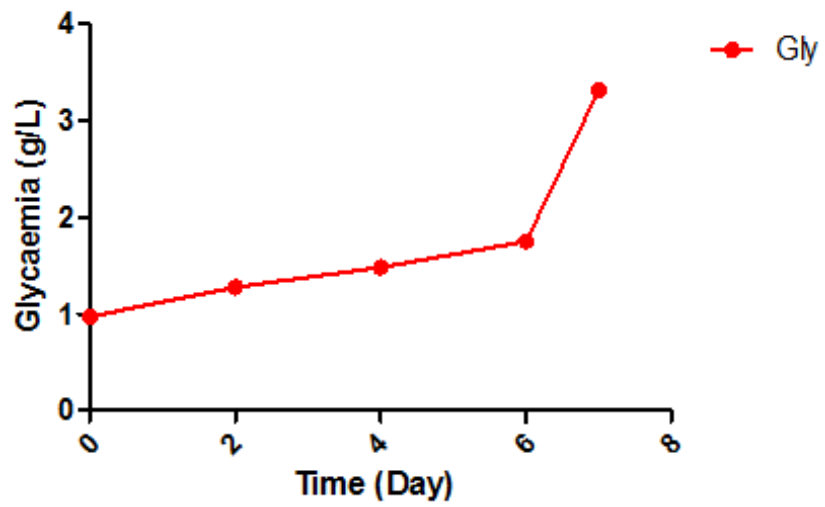

Gly: Glycaemia

Figure 1. Evolution of glycaemia after injection of streptozotocin

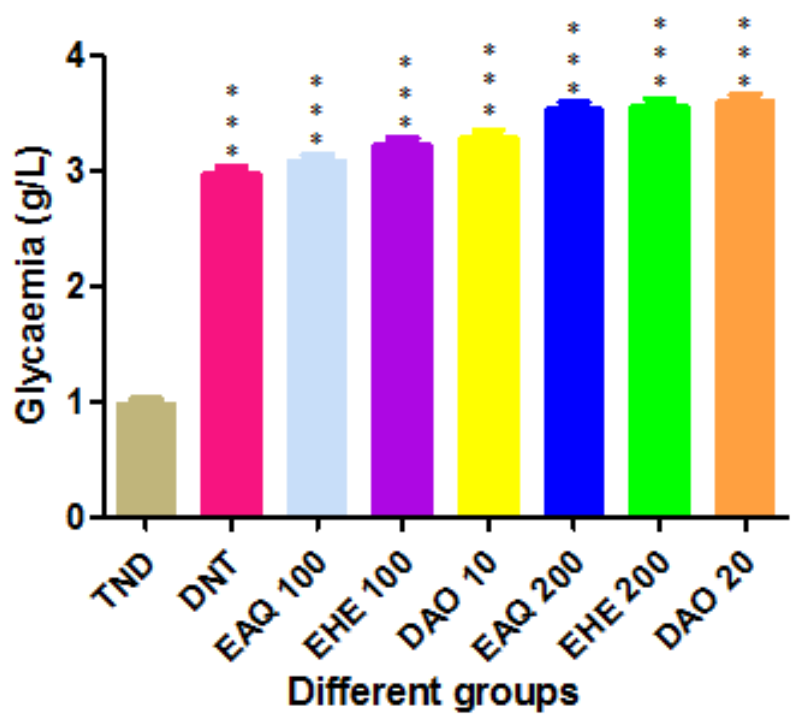

Each histogram represents the mean \pm SEM, $\mathrm{n}=6$.

*** $\mathrm{P}<0.001$ : Very highly significant difference compared to non-diabetic control rats (TND)

TND: Non-diabetic control rats

DNT: Untreated diabetic rats

EAQ 100: Diabetic rats will be treated with aqueous extract $(100 \mathrm{mg} / \mathrm{kg}$ bw)

EAQ 200: Diabetic rats will be treated with aqueous extract $(200 \mathrm{mg} / \mathrm{kg}$ bw)

EHE 100: Diabetic rats will be treated with ethylic alcohol extract (100 mg / $\mathrm{kg}$ bw)

EHE 200: Diabetic rats will be treated with ethylic alcohol extract (200 mg / $\mathrm{kg}$ bw)

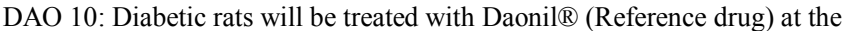
dose of $10 \mathrm{mg} / \mathrm{kg} \mathrm{bw}$

DAO 20: Diabetic rats will be treated with Daonil ${ }^{\circledR}$ (Reference drug) at the dose of $20 \mathrm{mg} / \mathrm{kg}$ bw

Figure 2. Glycaemia of rats before treatment 
3.4. Determination of Diabetic Rats Glycaemia after Treatment

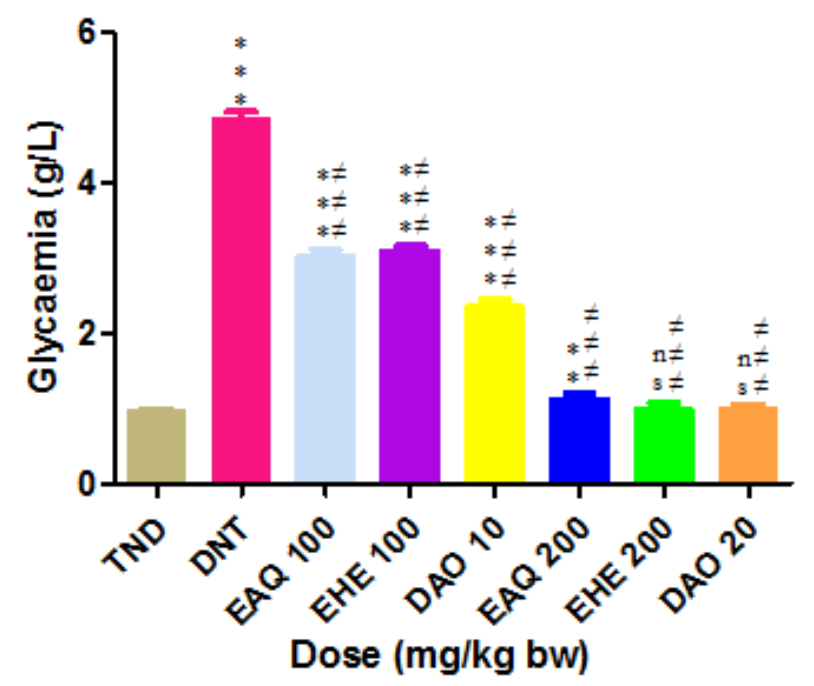

Each histogram represents the mean \pm SEM, $n=6$.

$* * * \mathrm{P}<0.001$ : Very highly significant difference compared to non-diabetic control rats (TND)

**P $<0.01$ : Very significant difference compared to non-diabetic control rats (TND)

ns: Non-significant difference compared to non-diabetic control rats (TND) $\neq \neq \neq \mathrm{P}<0.001$ : Very highly significant difference compared to untreated diabetic rats (DNT)

TND: Non-diabetic control rats

DNT: Untreated diabetic rats

EAQ 100: Diabetic rats treated with aqueous extract $(100 \mathrm{mg} / \mathrm{kg}$ bw)

EAQ 200: Diabetic rats treated with aqueous extract $(200 \mathrm{mg} / \mathrm{kg} \mathrm{bw})$

EHE 100: Diabetic rats treated with ethylic alcohol extract $(100 \mathrm{mg} / \mathrm{kg}$ bw $)$

EHE 200: Diabetic rats treated with ethylic alcohol extract $(200 \mathrm{mg} / \mathrm{kg}$ bw);

DAO 10: Diabetic rats treated with Daonil ${ }^{(}(10 \mathrm{mg} / \mathrm{kg}$ bw $)$

DAO 20: Diabetic rats treated with Daonil $\mathbb{}(20 \mathrm{mg} / \mathrm{kg}$ bw $)$

Figure 3. Glycaemia of diabetic rats after treatment

Fig. 3 shows the glycemia of diabetic rats after six days of treatment. Glycaemia in untreated diabetic rats increased from $2.98 \pm 0.06 \mathrm{~g} / \mathrm{L}$ to $4.87 \pm 0.08 \mathrm{~g} / \mathrm{L}$. This glycaemia is higher $(\mathrm{P}<0.05)$ than the glycaemia of non-diabetic control rats $(0.98 \pm 0.02 \mathrm{~g} / \mathrm{L})$. The glycaemia of diabetic rats treated with aqueous extract $(100 \mathrm{mg} / \mathrm{kg} \mathrm{bw})$, ethylic alcohol extract (100 mg / kg bw), Daonil ${ }^{\circledR}(10 \mathrm{mg} / \mathrm{kg} \mathrm{bw})$ and aqueous extract (200 $\mathrm{mg} / \mathrm{Kg} \mathrm{bw})$ remained significantly elevated $(\mathrm{P}<0.05)$ compared to glycaemia of non-diabetic control rats. These glycaemia respectively passed from 3.09 $\pm 0.05 \mathrm{~g} / \mathrm{L}, 3.23 \pm 0.06 \mathrm{~g} / \mathrm{L}, 3.30 \pm 0.06 \mathrm{~g} / \mathrm{L}$ and $3.54 \pm$ $0.06 \mathrm{~g} / \mathrm{L}$ to $3.04 \pm 0.08 \mathrm{~g} / \mathrm{L}, 3.11 \mathrm{~g} \pm 0.05 \mathrm{~g} / \mathrm{L}, 2.37 \pm 0.09$ $\mathrm{g} / \mathrm{L}$ and $1.13 \pm 0.08 \mathrm{~g} / \mathrm{L}$. Otherwise, glycaemia in diabetic rats treated with ethylic alcohol extract $(200 \mathrm{mg} / \mathrm{kg} \mathrm{bw})$ and Daonil ${ }^{\circledR}(20 \mathrm{mg} / \mathrm{kg} \mathrm{bw})$ respectively decreased from $3.57 \pm$ $0.05 \mathrm{~g} / \mathrm{L}$ and $3.61 \pm 0.06 \mathrm{~g} / \mathrm{L}$ to $1.01 \pm 0.06 \mathrm{~g} / \mathrm{L}$ and 0.99 $\pm 0.07 \mathrm{~g} / \mathrm{L}$. These glycaemia became similar $(\mathrm{P}>0.05)$ to the glycaemia of non-diabetic control rats.

Treatment of diabetic rats with aqueous extract (100 and $200 \mathrm{mg} / \mathrm{kg} \mathrm{bw}$ ), ethylic alcohol extract (100 and $200 \mathrm{mg} /$ $\mathrm{kg}$ bw) and Daonil ${ }^{\circledR}(10$ and $20 \mathrm{mg} / \mathrm{kg}$ bw) decreased significantly $(\mathrm{P}<0.05)$ the glycaemia compared to glycaemia of untreated diabetic rats.

\subsection{Determination of Diabetic Rats Insulinemia after Treatment}

Fig. 4 shows the effect of Daonil ${ }^{\circledR}$ and aqueous and ethylic alcohol extracts of Xylopia villosa on the insulin secretion of diabetic rats. The insulin concentration of untreated diabetic rats was $0.68 \pm 0.15 \mathrm{IU} / \mathrm{mL}$ versus $4.01 \pm$ $0.10 \mathrm{IU} / \mathrm{mL}$ in non-diabetic control rats. This insulin concentration in untreated diabetic rats dropped significantly $(\mathrm{P}<0.05)$ compared to insulin in non-diabetic control rats. For rats treated with aqueous extract $(100 \mathrm{mg} / \mathrm{kg} \mathrm{bw})$, ethylic alcohol extract $(100 \mathrm{mg} / \mathrm{kg}$ bw), Daonil $\mathbb{R}(10 \mathrm{mg} /$ $\mathrm{kg} \mathrm{bw})$ and aqueous extract ( $200 \mathrm{mg} / \mathrm{kg}$ bw $)$, Insulin concentrations were $1.06 \pm 0.02 \mathrm{IU} / \mathrm{mL}, 1.15 \pm 0.01 \mathrm{IU} /$ $\mathrm{mL}, 1.90 \pm 0.04 \mathrm{IU} / \mathrm{mL}$ and $3.53 \pm 0.05 \mathrm{IU} / \mathrm{mL}$, respectively. These insulin concentrations decreased significantly $(\mathrm{P}<0.05)$ relative to the insulin concentration of non-diabetic control rats. However, insulin concentrations in diabetic rats treated with ethylic alcohol extract $(200 \mathrm{mg} /$ $\mathrm{kg} \mathrm{bw})$ and Daonil ${ }^{\circledR}(20 \mathrm{mg} / \mathrm{kg} \mathrm{bw})$ were respectively 3.96 $\pm 0.10 \mathrm{IU} / \mathrm{mL}$ and $3.97 \pm 0.09 \mathrm{IU} / \mathrm{mL}$. These insulin concentrations were not significantly different $(\mathrm{P}>0.05)$ compared to the insulin concentration of non-diabetic control rats.

Treatment of diabetic rats with aqueous extract (100 and $200 \mathrm{mg} / \mathrm{kg} \mathrm{bw}$ ), ethylic alcohol extract (100 and $200 \mathrm{mg} /$ $\mathrm{kg}$ bw) and Daonil ${ }^{\circledR}(10$ and $20 \mathrm{mg} / \mathrm{kg}$ bw) increased significantly $(\mathrm{P}<0.05)$ insulin secretion of diabetic rats compared to glycaemia of untreated diabetic rats. 


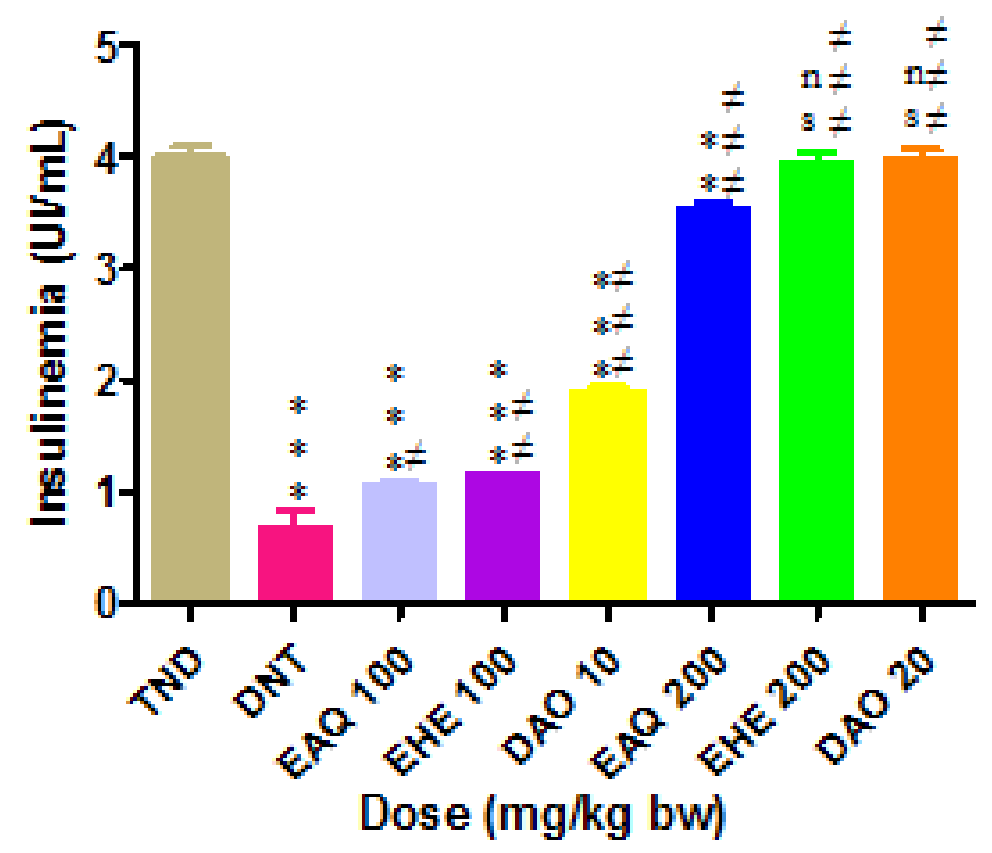

Each histogram represents the mean $\pm \mathrm{SEM}, \mathrm{n}=6$.

*** $\mathrm{P}<0.001$ : Very highly significant difference compared to non-diabetic control rats (TND)

**P $<0.01$ : Very significant difference compared to non-diabetic control rats (TND)

ns: Non-significant difference compared to non-diabetic control rats (TND)

$\neq \neq \neq \mathrm{P}<0.001$ : Very highly significant difference compared to untreated diabetic rats (DNT)

TND: Non-diabetic control rats

DNT: Untreated diabetic rats

EAQ 100: Diabetic rats treated with aqueous extract (100 mg / kg bw)

EAQ: Diabetic rats treated with aqueous extract $(200 \mathrm{mg} / \mathrm{kg}$ bw)

EHE 100: Diabetic rats treated with ethylic alcohol extract (100 $\mathrm{mg} / \mathrm{kg} \mathrm{bw})$

EHE 200: Diabetic rats treated with ethylic alcohol extract (200 $\mathrm{mg} / \mathrm{kg} \mathrm{bw})$;

DAO 10: Diabetic rats treated with Daonil $\mathbb{R}(10 \mathrm{mg} / \mathrm{kg} \mathrm{bw})$

DAO 20: Diabetic rats treated with Daonil $®(20 \mathrm{mg} / \mathrm{kg}$ bw $)$

Figure 4. Effect of Daonil, aqueous and ethanolic extracts on the insulin secretion of diabetic rats.

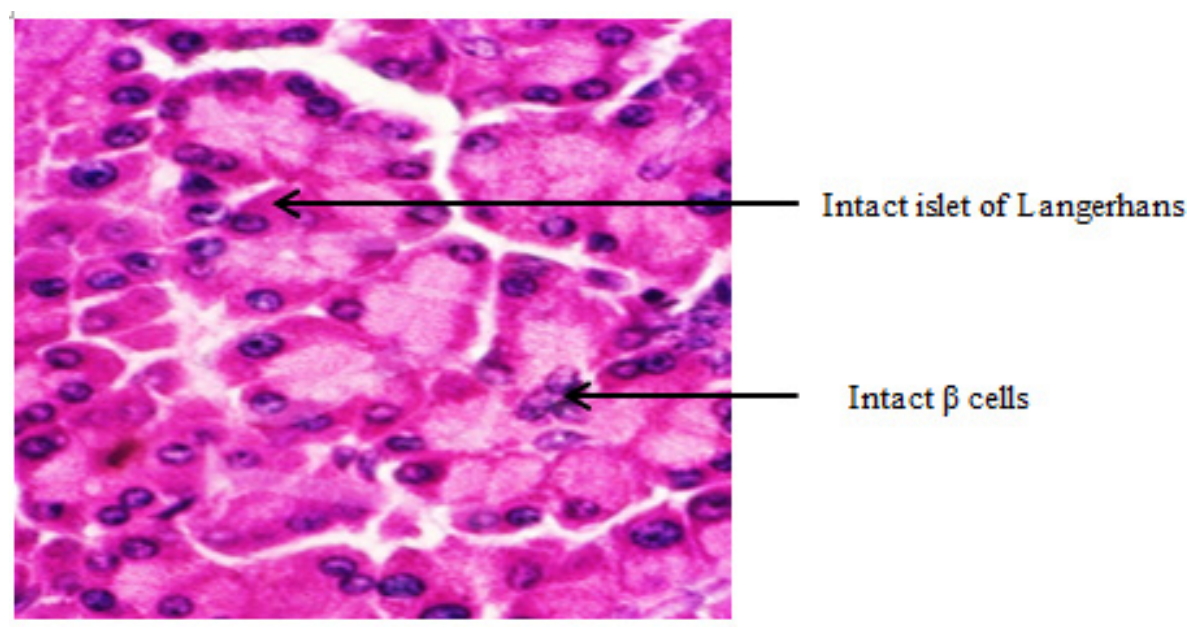

Figure 5a. Histological section of the pancreas of a non-diabetic witness rat 


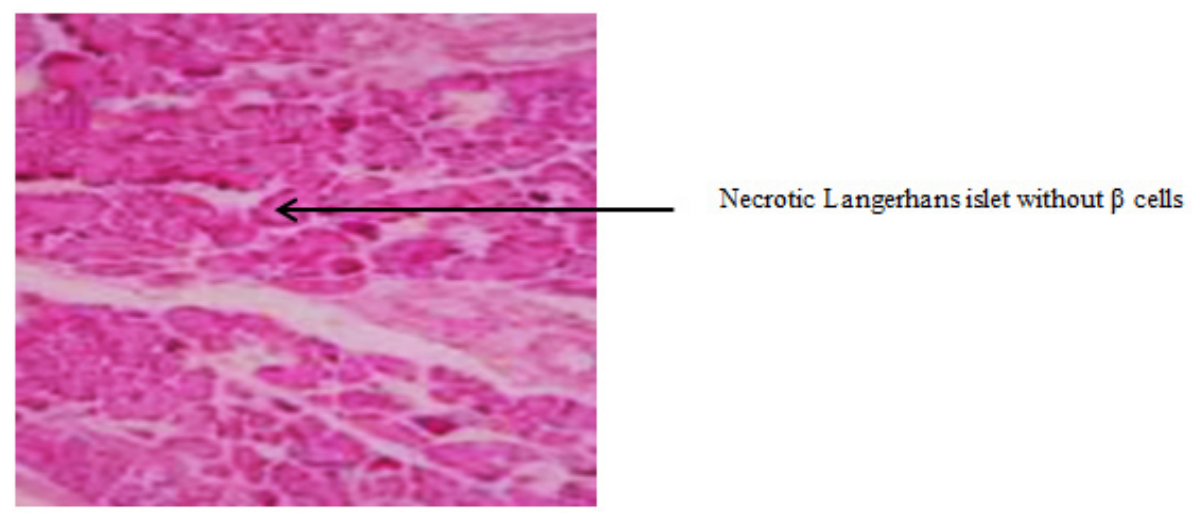

Figure 5b. Histological section of the pancreas of an untreated diabetic rat

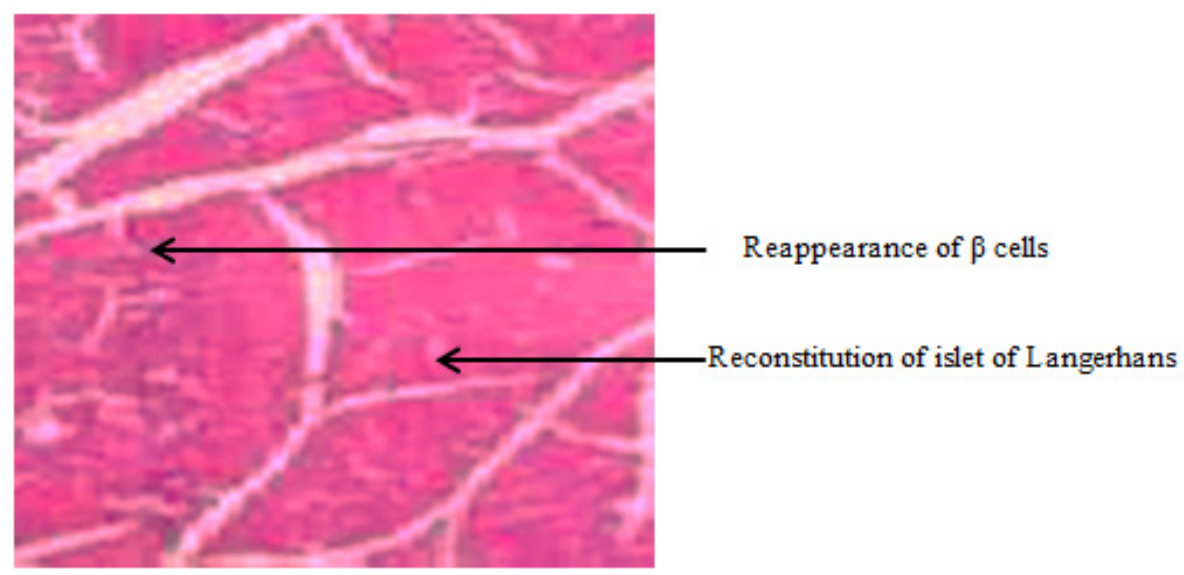

Figure 5c. Histological section of pancreas of a diabetic rat treated with ethylic alcohol extract $200 \mathrm{mg} / \mathrm{kg}$ bw

\subsection{Histological Sections}

The treatment of diabetic rats with the ethylic alcohol extract $(200 \mathrm{mg} / \mathrm{kg} \mathrm{bw})$ and Daonil (reference molecule) at a dose of $20 \mathrm{mg} / \mathrm{kg}$ bw favored reorganization of the islets of Langerhans and a reappearance of $\beta$ cells, showing as well as the ethylic alcohol extract $(200 \mathrm{mg} / \mathrm{kg} \mathrm{bw})$ and Daonil $(20 \mathrm{mg} / \mathrm{kg}$ bw) are gradually eliminating the deleterious effects of sptreptozocin on diabetic rats. In view of the results, the ethylic alcohol extract at the dose of 200 $\mathrm{mg} / \mathrm{kg}$ remains the necessary therapeutic dose having antidiabetic activity. In view of the antidiabetic activity of the stem bark of Xylopia villosa, it would be desirable to isolate and characterize molecules responsible for the activity quoted above by high performance liquid chromatography (HPLC).

\section{Discussion}

Induction of diabetes by streptozocin (STZ) in healthy rats resulted in three phases related to glycaemia. First, there was a significant increase of glycaemia in untreated rats compared to non-diabetic control rats. This increase of glycaemia is related to the streptozocin whose cytotoxic effect is selective of Langerhans islet cells [11-13]. Then, there was a second phase in which glycaemia of the diabetic rats treated with the aqueous extract (100 and $200 \mathrm{mg} / \mathrm{kg} \mathrm{bw}$ ), ethylic alcohol extract $\left(100 \mathrm{mg} / \mathrm{kg}\right.$ bw) and Daonil ${ }^{\circledR}(10$ $\mathrm{mg} / \mathrm{kg}$ bw) have been reduced but remained significantly elevated $(\mathrm{P}<0.05)$ compared to glycaemia of non-diabetic control rats. This result shows that these doses are not the therapeutic dose. Finally, a third phase in which glycaemia of diabetic rats treated with ethylic alcohol extract (200 $\mathrm{mg} / \mathrm{kg} \mathrm{bw})$ and Daonil ${ }^{\circledR}(20 \mathrm{mg} / \mathrm{kg} \mathrm{bw})$ decreased so as to have glycaemia equal $(\mathrm{P}>0.05)$ to that of non-diabetic control rats. This reduction of glycaemia in diabetic rats is related to the presence of flavonoids. Indeed, flavonoids improve the sensitivity of the body's cells to insulin, thus reducing the incidence of type-2 diabetes $[14,15]$.

The insulin secretion of diabetic rats had two phases. The first phase was characterized by a decrease in the insulin rate in the blood of untreated diabetic rats. This insulinopenia would justify the selective cytotoxic effect of Streptozocin (STZ) on $\beta$-cells of the islets of Langerhans [11-13]. Indeed, the STZ, once inside the cell, decomposes into reactive oxygenated species thus causing an alkylation of the DNA which is defragmented. This reaction consumes NAD and ATP as enzymatic cofactors leading to their depletion and necrosis of $\beta$ cells responsible for insulin secretion [16]. A second phase in which administration of ethylic alcohol extract $(200 \mathrm{mg} / \mathrm{kg} \mathrm{bw})$ and Daonil ${ }^{\circledR}(20 \mathrm{mg} / \mathrm{kg} \mathrm{bw})$ to 
diabetic rats resulted an insulin secretion rate similar to that of non-diabetic control rats. This situation is related to the anthocyanins contained in the said extracts. Indeed, anthocyanins, in addition to their antioxidant power increase the secretion of insulin [17]. These results are in agreement with those of Qin and Anderson [18], Jiao et al. [19] and Anderson et al. [20] who showed that the polyphenolic compounds of cinnamon identified as potentiators of insulin were proanthocyanidins, potentially hypoglycemic and antioxidants. The determination of the trace elements in the aqueous and ethylic alcohol extracts of Xylopia villosa revealed the presence of zinc. Zinc, in addition to being a powerful antioxidant, would have a protective insulin action. Zinc allows to activate the kinases involved in insulin signaling and the phosphorylations necessary for insulin efficacy [21].

\section{Conclusions}

The treatment of diabetic rats with the ethylic alcohol extract (200 mg/kg bw) and Daonil ${ }^{\circledR}$ (Reference drug) at a dose of $20 \mathrm{mg} / \mathrm{kg}$ bw favored reorganization of the islets of Langerhans and a reappearance of $\beta$ cells. At the dose of $200 \mathrm{mg} / \mathrm{kg}$, ethylic alcohol extract gradually eliminates the deleterious effects of streptozocin on diabetic rats. In view of the results, ethylic alcohol extract at the dose of $200 \mathrm{mg}$ $/ \mathrm{kg}$ remains the necessary therapeutic dose having antidiabetic activity. In view of the antidiabetic activity of the stem bark of Xylopia villosa, it would be desirable to isolate and characterize molecules responsible for the activity quoted above by high performance liquid chromatography (HPLC).

\section{Ethical Clearance}

The experimental procedures and protocols used in this study were approved by the Ethical Committee of Health Sciences, University Félix Houphouet-Boigny. These guidelines were in accordance with the European Council Legislation $87 / 607 /$ EEC for the protection of experimental animals. All efforts were made to minimize animal suffering and reduce the number of animals used.

\section{REFERENCES}

[1] World Diabetes Report, World Health Organization, Geneva, 2016. www.who.int/mediacentre/factsheets/fs312/fr/

[2] C.D Mathers, D. Loncar. Projections of global mortality and burden of disease from 2002 to 2030. PLoS Med, 3(11): e442, 2006.

[3] L. Aké-Assi. Flore de la Côte d'Ivoire: catalogue systématique, biogéographique et écologie. II. Boissiera 58, 2002.
[4] H.M. Burkill. The useful plants of west tropical Africa. Editions Royal Botanic Gardens, Kew, 960p, 1985.

[5] Y.Y. Kouame, A.T. Okpekon, H.F. Yapi, K.G. Gbassi, Y.J. Assi, Y.K.F Kouakou. Phytochemical screening and acute toxicity study of Xylopia villosa (annonaceae) barks stems of aqueous and hydroethanolic extracts. European Journal of Pharmaceutical and Medical Research 3(6), 526-531, 2016.

[6] Y.Y. Kouame, A.T. Okpekon, H.F. Yapi, K.G. Gbassi. Evaluation of Anti-Inflammatory Activities of Aqueous and Ethanolic Extracts of Xylopia villosa (Annonaceae). Asian Journal of Biochemical and Pharmaceutical Research Issue 3 (Vol. 6), 2231-2560, 2016.

[7] Y.Y. Kouame, A.T. Okpekon, G.L. Niamketchi, K.G. Gbassi, H.F. Yapi. Evaluation of antioxidant activity of aqueous and ethanolic extracts of stem bark of xylopia villosa chipp (annonaceae). International Journal of Biochemistry and Biophysics 4(3): 25-30, 2016.

[8] M. Clement, P. Francoise. Analyse chimique des sols. Édition Tec et Doc, 387 p, 2003.

[9] N. Tietz. Fundamentals of Clinical Chemistry. Ed WB Saunders Co: Philadelphia, 3; 427p, 1987.

[10] J.P. Raufman, L.Singh, G. Singh, J. Eng. Truncated glucagon-like peptide-1 interacts with exendin receptors on dispersed acini from guinea pig pancreas. Identification of a mammalian analogue of the reptilian peptide exendin- 4 . 267(30): 21432-2147. (1992).

[11] T. Anderson, P.S Schein, M.G McMenamin, D.A Cooney. Streptozotocin Diabetes: Correlation with extent of depression of pancreatic islet nicotinamide adenine dinucleotide. Journal of clinical investigation. 1974; 54:672-677.

[12] R. Crouch, G. Kimsey, D.G Priest, A. Sarda, M.G. Buse. Effect of streptozotocin on erythrocyte and retinal superoxide dismutase. Diabetologia. 1978; 15:53-57.

[13] M.J. Robbins, R.A. Sharp, A.E. Slonim, I.M. Burr. Protection against streptozotocin induced diabetes by superoxide dismutase. Diabetologia. 1980; 18:55-58.

[14] M.E. Lean, M. Noroozi, I. Kelly, J. Burns, D. Talwar, N. Sattar, A. Crozier. Dietary flavonols protect diabetic human lymphocytes against oxidative damage to DNA. Diabetes, 48 (1): 176-81.

[15] E.S. Ford, M.E. Cogswell. Diabetes and serum ferritin concentrations among US adults. Diabetes care, 22 (12): 1978 - 1983, 1999.

[16] T. Szkudelski. The Mechanism of Alloxan and Streptozotocin Action in B Cells of the Rat Pancreas. Physiol. Res. 50: 536 546, 2001.

[17] D. Ghosh. Ph.D. Les anthocyanes dans les aliments et le diabète

www.sinquery.com/les-anthocyanes-dans-les-aliments-et-lediabete/

[18] B. Qin, K.S. Panickar, R. Anderson. Cinnamon: potential role in the prevention of insulin resistance, metabolic syndrome and type 2 diabetes. J Diabetes Sci Technol. 4 (3) : 685-93, 2010.

[19] L. Jiao, X. Zhang, L. Huang, H. Gong, B. Cheng, Y. Sun, Y. Li, Q. Liu, L. Zheng, K. Huang. Proanthocyanidins are the 
major anti-diabetic components of cinnamon water extract. Food Chem Toxicol. 56: 398-405, 2013.

[20] R.A. Anderson, C.L. Broadhurst, M.M. Polansky, W.F. Schmidt, A. Khan, V.P. Flanagan, N.W. Schoene, D.J. Graves. Isolation and characterization of polyphenols type-A polymers from cinnamon with insulinlike biological activity. J Agric Food Chem. 2004, 52 (1):65- 70, 2004.

[21] G. Vardatsikos, N.R. Pandey, A.K. Srivastava. Insulino-mimetic and antidiabetic effects of zinc. Journal of Inorganic Biochemistry; 120: 8-17, 2013. 